\title{
Effects of Hydrogels on Tree Seedling Performance in Temperate Soils before and after Water Stress
}

\author{
Lawrence J. B. Orikiriza ${ }^{{ }^{*}}$, Hillary Agaba ${ }^{2}$, Gerald Eilu ${ }^{1}$, John D. Kabasa ${ }^{3}$, Martin Worbes ${ }^{4}$, \\ Aloys Hüttermann ${ }^{5}$ \\ ${ }^{1}$ School of Forestry, Environmental and Geographical Sciences, Makerere University, Kampala, Uganda; ${ }^{2}$ National Forestry Re- \\ sources Research Institute, Kampala, Uganda; ${ }^{3}$ Department of Biosecurity, Ecosystems and Veterinary Public Health, Makerere \\ University, Kampala, Uganda; ${ }^{4}$ Department for Crop Sciences, Institute of Tropical Agriculture, University of Goettingen, Goettin- \\ gen, Germany; ${ }^{5}$ Faculty of Forest Sciences and Forest Ecology, University of Goettingen, Goettingen, Germany. \\ Email: ${ }^{*}$ orikiriza@forest.mak.ac.ug
}

Received April 15 ${ }^{\text {th }}, 2013$; revised May $16^{\text {th }}, 2013$; accepted June $14^{\text {th }}, 2013$

Copyright (C) 2013 Lawrence J. B. Orikiriza et al. This is an open access article distributed under the Creative Commons Attribution License, which permits unrestricted use, distribution, and reproduction in any medium, provided the original work is properly cited.

\begin{abstract}
Super Absorbent Polyacrylate (SAP) hydrogels absorb and store water thereby aiding plant establishment when incurporated in the soil. The effect of cross-linked SAP hydrogel amendment on the performance of tree seedlings of Picea abies, Pinus sylivestris and Fagus sylvatica grown in temperate soils under water stress and non-water stress periods was investigated in a green house. The objective was to compare the root and shoot biomass of seedlings of the three species grown in sand, loam and clay soils amended with $0.4 \% \mathrm{w} / \mathrm{w}$ hydrogel in non water stress conditions as well as survival, root and shoot biomass after subjection to water stress. The seedlings were grown for 16 weeks, harvested and shoot as well as root biomass determined before water stress. The seedlings were also subjected to water stress and their biomass assessed at death following the water stress. The results showed that root and shoot biomass were generally higher in hydrogel amended soils compared to the controls. Root and shoot biomass of Fagus sylvatica was lower compared to Picea abies and Pinus sylivestris before water stress. The $0.4 \%$ hydrogel amendment significantly increased species' survival in the different soils studied. Although root biomass was higher in hydrogel amended sandy soil compared to other soils, P. sylivestris and F. sylvatica shoot biomass were higher in hydrogel amended clay and loam soils compared to the sandy soil after water stress. Biomass was higher in sand compared to loam and clay soils under non-water and water stressed conditions. Since SAP hydrogel amendment improved the survival and biomass production of tree seedlings before and after water stress, use of SAPs could be promoted to enhance seedling production in water stress and non-water stress environments.
\end{abstract}

Keywords: Desiccation; Non-Water Stress; SAPs; Soil Amendment; Tree Species

\section{Introduction}

Water scarcity is a challenge to agriculture and plantation forestry in many parts of the tropical and temperate regions in the world. Water saving technologies that enhance plant establishment and growth in soils of different properties are required. Soils generally differ in moisture content, temperature and mineralogy [1] which may require different soil moisture conservation technologies. One available technology is the use of super absorbent hydrophilic polymers [2]. Super absorbent polymers (SAPs) are substances that can retain large quantities of water and nutrients when incorporated in the soil, making

"Corresponding author. it available for plant growth whenever required. They can be linear or cross-linked hydrogels [3] based on the structure of the cross-linking agents. This study focused on the latter type that has a relatively higher water absorption capacity compared to the former. The soil water and nutrients stored in SAPs are released gradually for plant growth under water limiting conditions $[4,5]$ whereas under non-water limiting conditions, they are reported to enhance nutrient uptake for plant growth [3].

Different soils and tree species exhibit varying responses to SAP hydrogel amendment. Several studies have shown that addition of hydrogels to growing media increased water holding capacity by up to $400 \%$ [6] and decreased water stress by delaying the onset of wilting 
[7]. In water-stressed soils for instance, prolonged survival and improved growth have been recorded under drought conditions [8-12] and in sandy desert soils [13]. SAPs were reported to increase tree species survival and reduce evapo-transpiration in different soils under drought conditions [14]. Improved growth has also been reported in seedlings grown in well watered sandy soil [15] as well as tropical soils [16].

Since the effects of SAP hydrogels on trees grown in temperate soils and specifically under non-water stress conditions are not known, it is necessary to understand the behaviour of SAPs in a wide range of soils in order to recommend which trees for what type of soils. Most studies on hydrogel application have been conducted on sandy soils [17-22] with less attention to loamy and clayey soils. Thus, the behavior of hydrogels in the latter soils remains largely unexplored and could potentially limit their application over a wide range of agro-ecological zones. This study therefore investigated tree seedlings performance in temperate soils before and after water stress. The objective of the study was to compare survival and biomass of seedlings of the following tree species (Picea abies (L.) (H. Karst.) (Spruce), Pinus sylivestris L. (Pine) and Fagus sylvatica L. (Beech) in temperate soils amended with SAPs before and after water stress. The following hypotheses were tested: 1) Hydrogel amendment increases the biomass of tree seedlings in sandy, loamy and clayey soils before water stress, 2) Hydrogel amendment prolongs the survival time of tree seedlings in sandy, loamy and clayey soils exposed to drought and 3) There is no difference in tree biomass between hydrogel amended soils before and after subjecttion to water stress.

\section{Materials and Methods}

\subsection{Soils}

Sand, loam and clay soils were used in the study. The sand was obtained from a sand pit in Schöningen (Longitude $9^{\circ} 40^{\prime} 0^{\prime \prime}$ E Latitude: $51^{\circ} 38^{\prime} 0^{\prime \prime} \mathrm{N}$ ) in the Solling Mountains close to Göttingen, Germany. The loam soil was sampled from the field of the Institute for Tropical Agriculture, Georg August University Göttingen (Longitude $9^{\circ} 56^{\prime} 2^{\prime \prime}$ E Latitude $\left.51^{\circ} 32^{\prime} 1^{\prime \prime} \mathrm{N}\right)$. The clay soil was collected from the forest at the clay factory in Göttingen. Samples of the soils were collected from $30 \mathrm{~cm}$ deep 10 $\mathrm{m} \times 10 \mathrm{~m}$ pits and separately mixed into one composite sample each of about $2 \mathrm{~kg}$ at the Fakultät für Forstwissenschaften und Waldökosysteme, Soil science laboratory, Georg August University.

All samples were air dried, sieved through a $2 \mathrm{~mm}$ sieve, oven dried at $80^{\circ} \mathrm{C}$ for 72 hours and their chemical characteristics analyzed. A pH meter was used to determine the soil $\mathrm{pH}$ [23] while organic $\mathrm{C}$ and $\mathrm{N}$ were deter- mined by the Walkley-Black [24] and Kjeldahl [25] methods. Available phosphorus was analyzed using the Bray method $[26,24]$. Exchangeable cations $\left(\mathrm{Ca}^{2+}, \mathrm{Mg}^{2+}\right.$, $\mathrm{K}^{+}$and $\mathrm{Na}^{+}$) were extracted by shaking the soil sample for 2 hours with $1 \mathrm{M}$ Ammonium acetate [27]. Concentrations of $\mathrm{K}$ and $\mathrm{Na}$ were then determined by a flame photometer whereas $\mathrm{Ca}$ and $\mathrm{Mg}$ were determined by Atomic Absorption Spectrophotometry [26]. The characteristics of the soils are presented in Table 1.

\subsection{Plant Material}

Six month old seedlings of Picea abies (Spruce), Pinus sylivestris (Pine) and Fagus sylvatica (Beech) obtained from a commercial tree nursery in Göttingen Germany were used in the experiment. The seedlings were healthy and free from pests and diseases. These species were chosen because they are widespread in Europe, are found in a large range of ecological conditions and have economic value. Picea abies for example, is one of the most common and economically important coniferous species in Europe and Scandinavia and tolerates acidic soils although it is not well suited for dry or nutrient deficient soils [28]. Pinus sylvestris is native to Europe and Asia. It is an important plantation forestry tree that is used to reforest degraded coal mines and burned sites. Seedlings of Pinus sylvestris establish best in soils with adequate moisture and some shade. Survival is best when the seedlings are planted on microsites close to the tops of hills, and lowest in overly moist depressions. Fagus sylvatica, the European Beech or Common Beech, is a deciduous tree that grows well in almost any type of soil. However, it grows best in fairly humid areas with well-drained soils found on moderately fertile ground, calcified or lightly acidic.

\subsection{Hydrogel}

Luquasorb hydrogel manufactured by the BASF SE Chemical Company, Ludwigshafen, Germany was used to amend the different soils at $0.4 \%$ hydrogel concentra-

Table 1. Chemical characteristics of the soils used in the experiment.

\begin{tabular}{cccc}
\hline Parameter & Sand & Loam & Clay \\
\hline $\mathrm{pH}$ & 4.37 & 6.20 & 5.80 \\
Carbon (\%) & 0.06 & 0.70 & 0.40 \\
Nitrogen (\%) & 0.01 & 0.21 & 0.12 \\
Available Phosphorus (ppm) & 9.81 & 14.80 & 10.14 \\
Calcium (Meq/100g soil) & 1.47 & 3.00 & 1.82 \\
Magnesium (Meq/100g soil) & 0.33 & 0.93 & 1.03 \\
Potassium (Meq/100g soil) & 0.08 & 0.32 & 0.25 \\
Sodium (Meq/100g soil) & 0.06 & 0.12 & 0.15 \\
\hline
\end{tabular}


tion. The control had no hydrogel added. The $0.4 \%$ hydrogel concentration was made by mixing $4 \mathrm{~kg}$ of hydrogel powder with $1000 \mathrm{~kg}$ of soil prepared in a concrete mixer (Mini Concrete Mixer, Model: CM 180-MZ2; Mixing capacity $180 \mathrm{~L}$ ). The amount of hydrogel and the mixing procedure followed previous studies [4] and recommendations by the manufacturer.

\subsection{Treatments and Experimental Design}

Thirty five seedlings each of Picea abies, Pinus sylivestris and Fagus sylvatica were transplanted into $3 \mathrm{~kg}$ polythene pots each filled with sand, loam and clay soils amended at either $0.4 \%$ hydrogel or a control (no hydrogel amendment). Altogether this made 18 treatment combinations in a Randomized Factorial Design i.e. (Sand + hydrogel $\times 3$ tree species, Sand + control $\times 3$ tree species; Loam + hydrogel $\times 3$ tree species, Loam + control $\times 3$ tree species; Clay + hydrogel $\times 3$ tree species, Clay + control $\times 3$ tree species). Each of the 18 treatment combinations of seedlings in hydrogel amended or un amended soils were randomly placed in a green house and maintained at $25^{\circ} \mathrm{C}-32^{\circ} \mathrm{C}$ and relative humidity of $50 \%-95 \%$. Depending on whether or not the soils were saturated, the plants were watered for at least once a day for 16 weeks until they were established. Proper establishment was indicated by the growth of new leaves or needles and twigs.

\subsection{Determination of Biomass before Water Stress}

After 16 weeks, the seedlings were watered to field capacity (when the water settled on the soil surface and drainage became negligible). This ensured complete hydrogel expansion and soil saturation. Ten seedlings in each treatment combination were harvested and cut into two parts-roots and shoots, oven dried for 72 hours, then weighed using a sensitive Sartorius weighing scale (Model ED 8201-CW Extend Precision balance $8200 \times$ $0.1 \mathrm{~g}$ ) to give the dry weight before water stress. The roots were separated from the soil by gently washing under slow moving clean tap water.

\subsection{Determination of Survival and Biomass after Water Stress}

The remaining 25 were subjected to water stress by complete termination of watering and monitored daily to observe initiation of wilting, desiccation and death. The start date of desiccation was recorded (T1). The date when a seedling died was recorded (T2). The seedlings were monitored until the color of the stems, leaves, branches and/or needles changed from green to brown or grey. A plant was recorded as dead when all the leaves and stems turned brown and started falling off as branches became brittle. Brittleness was ascertained by breaking a sample branch which fell off confirming the brittleness. Roots and shoots were also oven dried for 72 hours, weighed using a sensitive Sartorius weighing scale (Model ED 8201-CW Extend Precision balance $8200 \times$ $0.1 \mathrm{~g}$ ) to obtain the dry weight after water stress.

\subsection{Data Analysis}

One-way Analysis of variance (ANOVA) was used to test the effect of the factors (hydrogel and soil types) on survival time and biomass production each tree species at $p<0.05$ in SPSS version 16. The mean root and shoot biomass across hydrogel levels were compared between soil types using paired $t$-tests. Biomass before and after desiccation was also compared using paired $t$-tests. All tests were carried out at $p<0.05$ level of significance.

\section{Results and Discussions}

\subsection{Effect of Hydrogel on Biomass in Non-Water Stressed Soils}

Root and shoot biomass of the three species were generally higher in hydrogel amended soils compared to the controls. However, Fagus sylvatica root and shoot biomass were generally lower than for Picea abies and Pinus sylivestris in hydrogel amended soils (Figure 1). Overall, root biomass was generally higher in hydrogel amended sandy soil compared to other soils. In the case of $P$. sylivestris and F. sylvatica, however, shoot biomass was higher in hydrogel amended clay and loam soils compared to the sandy soil (Figure 1).

These findings confirm that SAP hydrogel amendments improve tree growth performance in non-water stressed temperate soils. Hydrogel induced biomass responses between species and soils in this study concur with those obtained from green house experiments on tropical soils in Uganda [16]. Differences in the species' biomass accumulation responses to hydrogel amendment for instance, the generally lower biomass of Fagus sylvatica relative to Picea abies and Pinus sylivestris could be attributed to the different soil moisture requirements of tree species caused by genotypic differences between the species. Considering that soils with higher Cation Exchange Capacity (CEC) have the capacity to retain plant nutrients better [29], the increase in biomass when water is not limiting is possibly a result of improved nutrient availability to the plants, following SAP hydrogel application. It is possible that incorporation of hydrogels to soils provided additional adsorption of cations to the negative charges thereby increasing the soil base saturation hence enhancing biomass.

The relatively high root biomass in hydrogel amended 

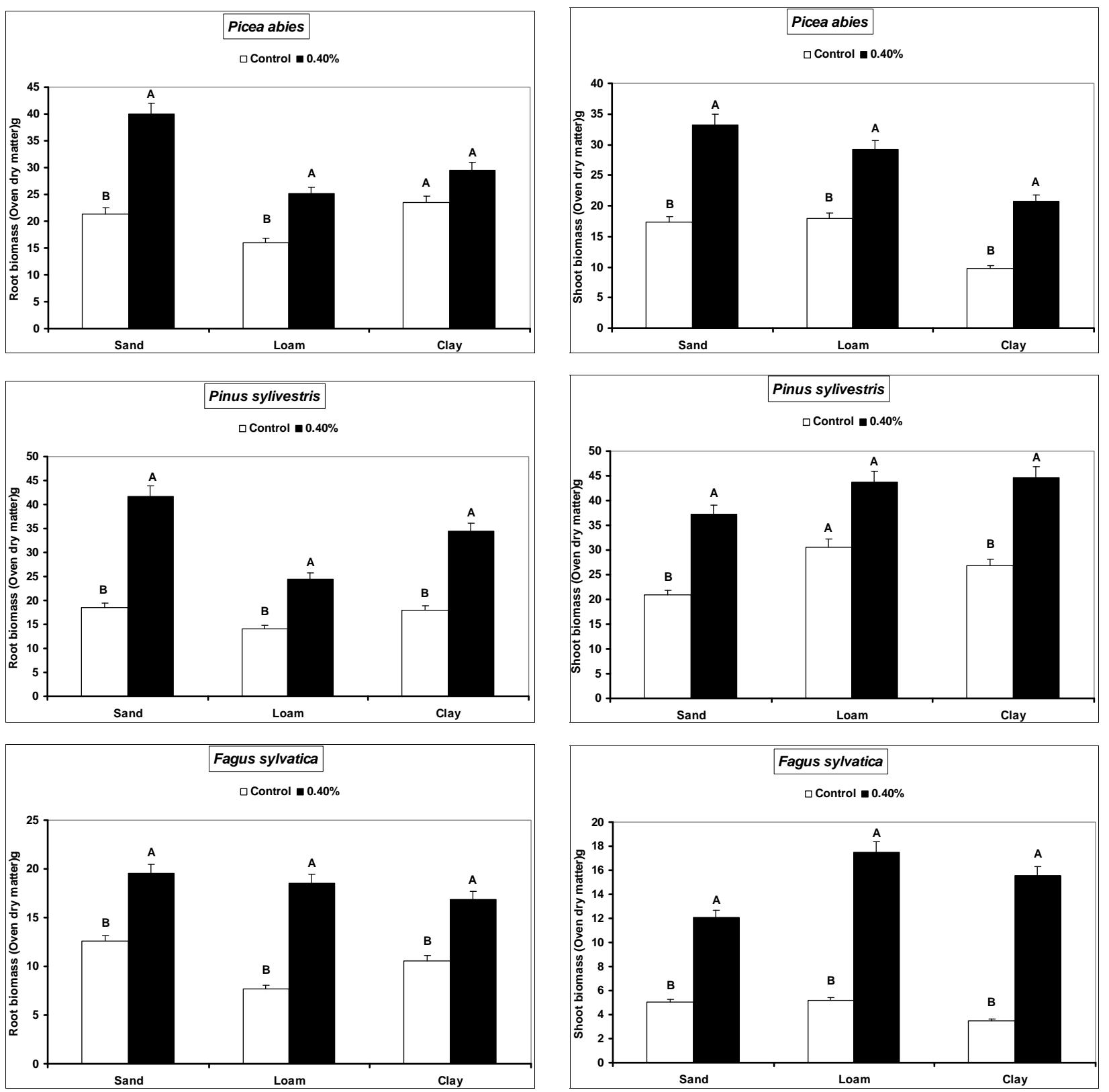

Figure 1. Root and shoot biomass responses of tree seedlings of Picea abies, Pinus sylivestris and Fagus sylvatica to hydrogel amendment in different soils before water stress. Each value is the mean of 5 plants. Different letters in the same bar cluster show significant differences.

sandy soil compared to other soils is related to the low water retention capacity of loam and clay soils. Divalent cations in soils (e.g. $\mathrm{Ca}^{2+}$ and $\mathrm{Mg}^{2+}$ ) can destroy the polymer lattice of hydrogels thus diminishing water retention by the gel [18]. Hydration of gels in the presence of divalent $\left(\mathrm{Ca}^{2+}\right.$ and $\left.\mathrm{Mg}^{2+}\right)$ and monovalent $\left(\mathrm{K}^{+}\right.$and $\mathrm{NH}^{4+}$ at 20 meq. per liter) cations reduces from $10 \%$ and $20 \% \mathrm{mM}[30]$. The relatively high levels of these elements in loam and clay soils relative to sand (Table 1) therefore partly explain the observed biomass differences. However, the effect of calcium and magnesium cations on water absorption by loam and clay soils was not spe- cifically investigated.

\subsection{Hydrogel Effect on Seedling Survival and Biomass in Water Stressed Soils}

Survival time of Picea abies, Pinus sylivestris and Fagus sylvatica seedlings significantly increased in the $0.4 \%$ hydrogel amended sand, loam and clay soils compared to the controls (Figure 2). In hydrogel amended soils survival was 66, 71 and 57 days more in sand, 8, 11 and 3 days more in loam and 17, 3 and 4 days more in clay soils respectively for Picea abies, Pinus sylivestris and 

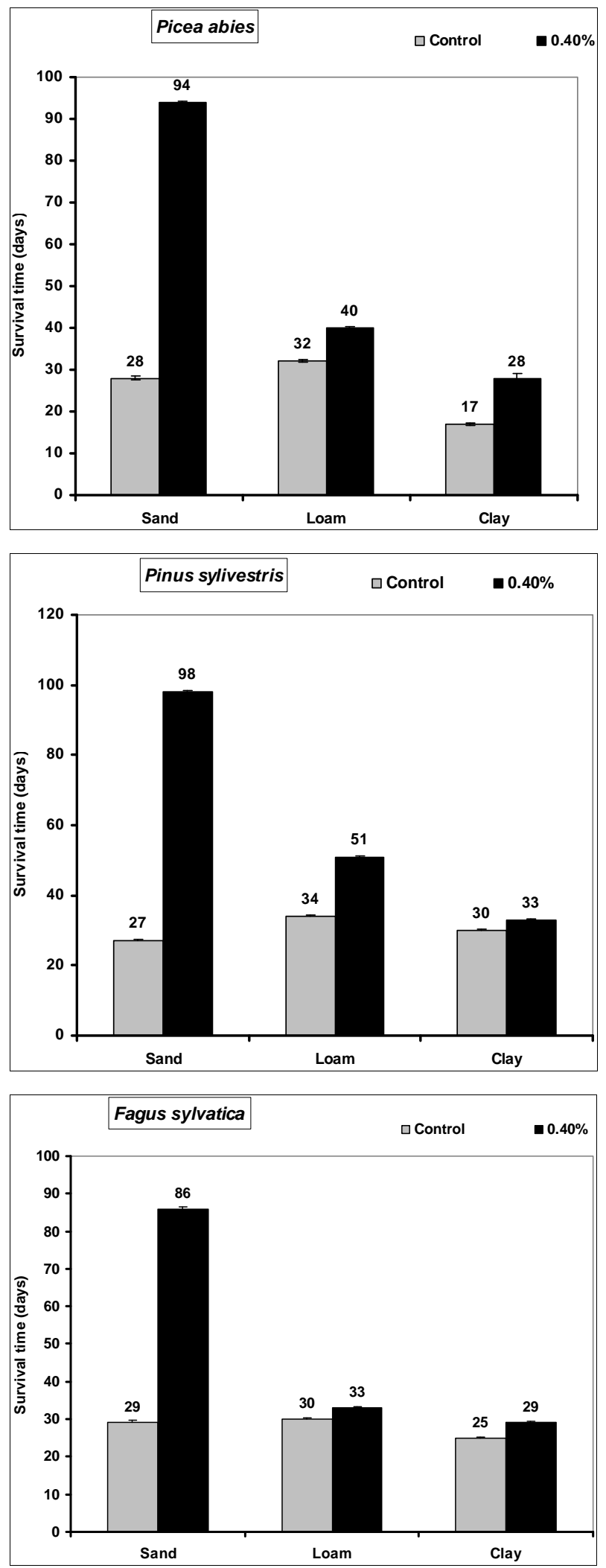

Figure 2. Survival time after water stress of selected tree seedlings grown in different soils amended with hydrogel. Each value is the mean of 5 plants. Error bars indicate standard error of the mean.
Fagus sylvatica seedlings compared to the controls. Species' root and shoot biomass was generally higher in hydrogel amended soils compared to the controls (Figure 3).

The higher duration of species' seedling survival, root and shoot biomass responses in hydrogel amended soils compared to the controls, confirm that SAP hydrogel amendment improves survival and tree growth performance in water stressed temperate soils. Hydrogels enhance the water holding capacity of soils and thus provide supplementary plant available water to plant root zones in dry soils $[13,31]$. Whereas biomass was higher in hydrogel amended soils compared to the controls, the effect was higher in sand compared to loam and clay (i.e. overall, hydrogel had a marginal effect on root biomass in clay and loam soils). Our results on improved survival time, root and shoot biomass growth during water stress conditions agree with previous studies in different media, $[11,32,33,34]$. Despite the differences (e.g. in water retention) between hydrogel amended temperate soils [35], the relatively higher root and shoot biomass responses for $P$. abies and $P$. sylivestris compared to $F$. sylvatica may be explained by the genotypic differences between tree species [36]. Earlier studies (e.g. [18,36] report similar different plant responses to hydrogel treatments in drought stressed soils). The magnitude of increase in biomass following hydrogel amendment may be attributed to the differences in strategies of species in responding to water stress $[37,38]$. Although prolonged water stress inhibits plant growth through its effects on physiological processes such as $\mathrm{CO}_{2}$ assimilation [11] hydrogel amendment improves the photosynthetic rate, root growth, reducing $\mathrm{CO}_{2}$ assimilation and stomatal conductance inhibition caused by water stress [11]. It is thus likely that the species used in this experiment, strategically partitioned resources in response to water stress; with for instance Picea abies and Pinus sylivestris dramatically developing more root and shoot biomass, whereas Fagus sylvatica reduced root biomass. This is especially beneficial in dry environments where more root growth implies increased capacity to absorb the scarce water resources whereas increased shoot growth means a larger leaf area for photosynthesis with more growth [39] and enhanced water use efficiency. Hydrogel amended sandy soils have a higher water retention capacity $[2,14]$. It is also possible that large pore spaces in sandy soils allow more swelling of the hydrogel thereby providing more supplementary water available for plant growth compared to the loam and clay soils.

\subsection{Change in Biomass during Water Stress}

Total biomass (root and shoot) in hydrogel amended soils ranged from 5 to 45 times higher in hydrogel amended soils when compared to the controls after subjecting trees to water stress (Figure 4). However, total biomass gen- 

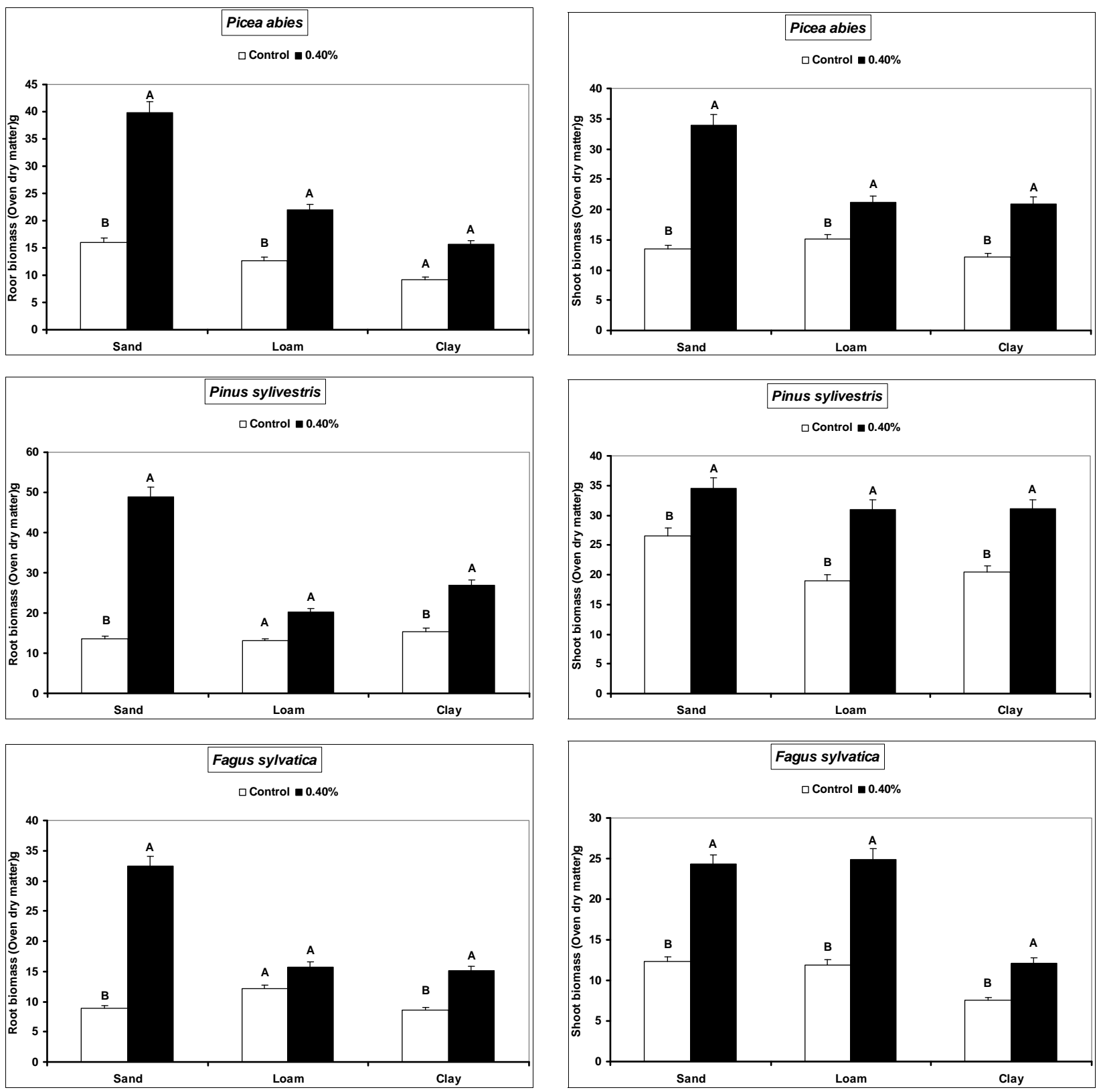

Figure 3. Responses of different tree species to hydrogel amendment during water stress conditions. Each value is the mean of 5 plants. Different letters in the same bar cluster are significantly different.

erally reduced following water stress although some increases were recorded in hydrogel amended sand and loam soils (Figure 4).

Changes in total biomass for the species in hydrogel amended soils are signals of physiological adjustments to water stress. This partly accounts for the observed biomass increases in sand and loam soils amended with hydrogel during desiccation. Reduced biomass in hydrogel amended soils appears to be related to the ability of hydrogels to delay drought stress effects [33]. However, the fact that hydrogels enhanced total biomass in different soils before and after desiccation, implies that hydrogels can be applied in soils with different moisture contents (i.e. from dry to saturated at field capacity).

\section{Conclusion}

In conclusion, hydrogel amendment increased tree seedling root and shoot biomass of Picea abies, Pinus sylivestris and Fagus sylvatica seedlings in sand, loam and clay soils in non-water stressed soils. Under water stressed conditions, hydrogel amendment prolonged the species' survival and improved biomass in sandy soils compared to other soils. Species' biomass generally reduced the following water stress. Such effects of SAPs 
$\mathrm{c}$
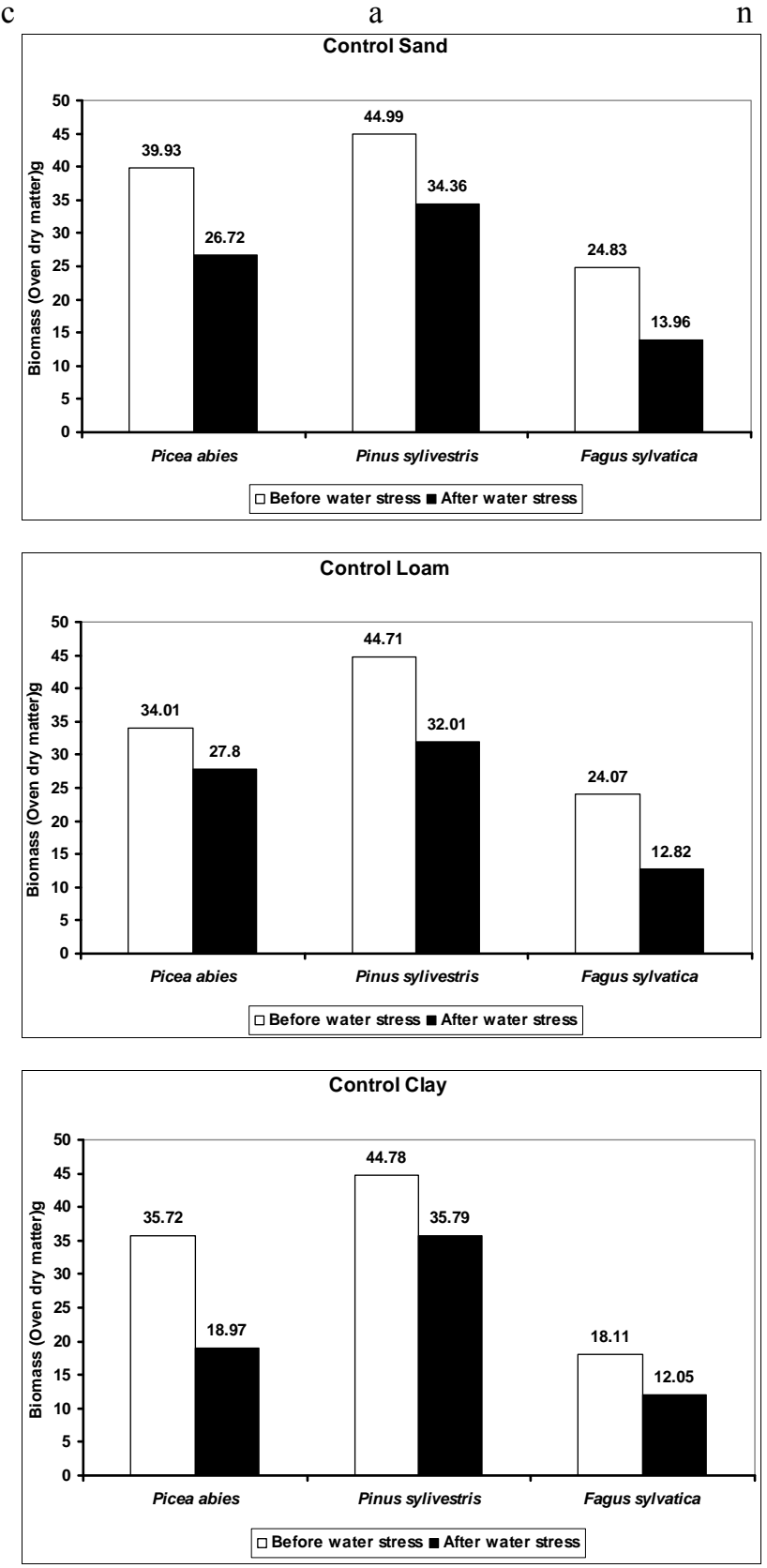
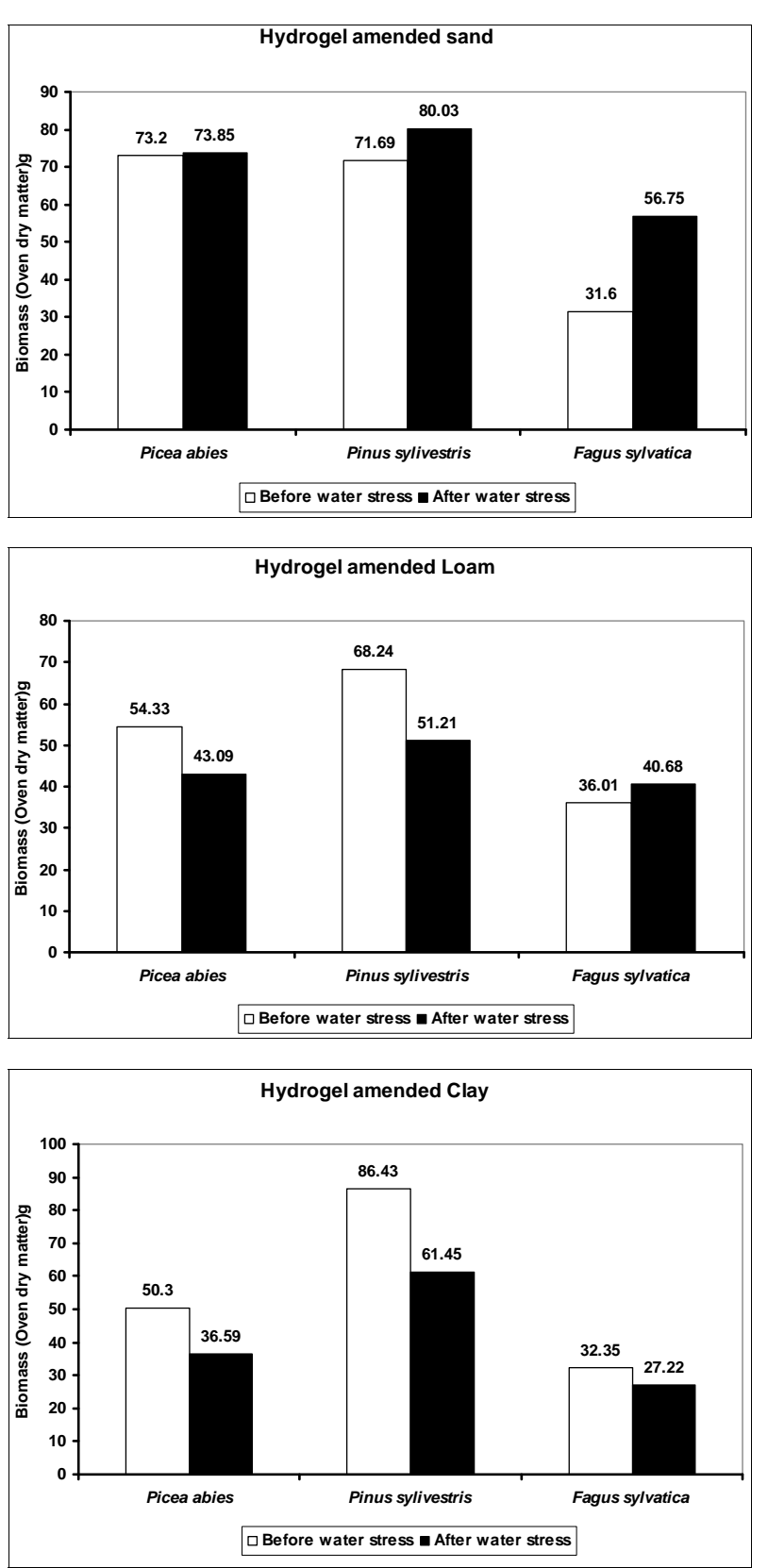

Figure 4. A comparison of the effect of hydrogel on total biomass (root and shoot) of selected species in different soils before and after desiccation. Each value indicated on the bars is the mean of 5 plants.

be used to promote tree seedling production and planting programmes especially in water stress and non-water stress environments.

\section{Acknowledgements}

We are grateful to the KAAD and BASF SE, Chemical Company, Germany, for jointly funding this study and providing the stipends of Lawrence Orikiriza and Hillary Agaba. We also pay a special tribute to Prof. Dr. Aloys Hüttermann who passed on during the preparation of this work. We dedicate this work to his honor and memory.

\section{REFERENCES}

[1] J. Six, C. Feller, K. Denef, S. M. Ogle, J. C. Moraes Sa and A. Albrecht, "Soil Organic Matter, Biota and Aggregation in Temperate and Tropical Soils-Effects of NoTillage," Agronomie, Vol. 22, No. 7-8, 2002, pp. 755-775. doi:10.1051/agro:2002043

[2] S. S. Dorraji, A. Golchin and S. Ahmadi, "The Effects of Hydrophilic Polymer and Soil Salinity on Corn Growth in Sandy and Loamy Soils," Clean-Soil, Air, Water, Vol. 38, No. 7, 2010, pp. 584-591. 
[3] A. Hüttermann, L. J. B. Orikiriza and H. Agaba, “Application of Superabsorbent Polymers for Improving the Ecological Chemistry of Degraded or Polluted Lands," Clean-Soil, Air, Water, Vol. 37, No. 7, 2009, pp. 517-526. doi:10.1002/clen.200900048

[4] A. Hüttermann, M. Zommorodi and K. Reise, "Addition of Hydrogels to Soil for Prolonging the Survival of Pinus halepensis Seedlings Subjected to Drought," Soil \& Tillage Research, Vol. 50, No. 3-4, 1999, pp. 295-304. doi:10.1016/S0167-1987(99)00023-9

[5] F. Yazdani, I. Allahdadi and G. A. Akbari, "Impact of Superabsorbent Polymer on Yield and Growth Analysis of Soybean (Glycine max L.) under Drought Stress Condition," Pakistan Journal of Biological Sciences, Vol. 10, No. 23, 2007, pp. 4190-4196. doi:10.3923/pjbs.2007.4190.4196

[6] M. S. Johnson, "Effects of Soluble Salts on Water Absorption by Gel-Forming Soil Conditioners," Journal of the Science of Food and Agriculture, Vol. 35, No. 10, 1984, pp. 1063-1066. doi:10.1002/jsfa.2740351004

[7] J. M. Gehring and A. J. Lewis, "Effects of Hydrogel on Wilting and Moisture Stress of Bedding Plants," Journal of the American Society for Horticultural Science, Vol. 105, No. 4, 1980, pp. 511-513.

[8] M. Sarvas, "Effect of Desiccation on the Root System of Norway Spruce (Picea abies [L.] Karst.) Seedlings and a Possibility of Using Hydrogel STOCKOSORB for Its Protection," Journal of Forest Science, Vol. 49, No. 11, 2003, pp. 531-536.

[9] E. M. A. Youssef, "Influence of Hydrogels Compounds on Acclimatization Behavior of Acacia Melanoxylon. Br. Vitroplants," Acta Horticulturae, Vol. 608, 2003, pp. 8184.

[10] J. Akhter, K. Mahmood, K. A. Malik, A. Mardan, M. Ahmad and M. M. Iqbal, "Effects of Hydrogel Amendment on Water Storage of Sandy Loam and Loam Soils and Seedling Growth of Barley, Wheat and Chickpea," Plant, Soil and Environment, Vol. 50, No. 10, 2004, pp. 463-469.

[11] V. Arbona, J. D. Iglesias, J. Jacas, E. Primo-Millo, M. Talon and A. Gomez-Cadenas, "Hydrogel Substrate Amendment Alleviates Drought Effects on Young Citrus Plants," Plant and Soil, Vol. 270, No. 1, 2005, pp. 73-82. doi:10.1007/s11104-004-1160-0

[12] K. G. Apostol, D. F. Jacobs and R. K. Dumroese, "Root Desiccation and Drought Stress Responses of Bare Root Quercus rubra Seedlings Treated with a Hydrophilic Polymer Root Dip," Plant and Soil, Vol. 315, No. 1-2, 2009, pp. 229-240. doi:10.1007/s11104-008-9746-6

[13] J. Abedi-Koupai, S. S. Eslamian and J. A. Kazemi, "Enhancing the Available Water Content in Unsaturated Soil Zone Using Hydrogel, to Improve Plant Growth Indices," Ecohydrology and Hydrobiology, Vol. 8, No. 1, 2008, pp. 67-75.

[14] H. Agaba, L. J. B. Orikiriza, J. F. O. Esegu, J. Obua, J. D. Kabasa and A. Hüttermann, "Effect of Hydrogel Amendment to Different Soils on Plant Available Water and Survival of Trees under Drought Conditions," Clean-Soil, Air, Water, Vol. 38, No. 4, 2010, pp. 328-335.

\section{doi:10.1002/clen.200900245}

[15] J. P. Syvertsen and J. M. Dunlop, "Hydrophilic Gel amendments to Sand Soil Can Increase Growth and Nitrogen Uptake Efficiency of Citrus Seedlings," Horticultural Science, Vol. 39, 2004, pp. 267-271.

[16] L. J. B. Orikiriza, H. Agaba, G. Eilu, M. Tweheyo, J. D. Kabasa and A. Hüttermann, "Amending Soils Hydrogels Increases the Biomass of Nine Tree Species under NonWater Stress Conditions," Clean-Soil, Air, Water, Vol. 37, No. 8, 2009, pp. 615-620. doi:10.1002/clen.200900128

[17] K. C. Taylor and R. G. Halfacre, "The Effect of Hydrophilic Polymer on Media Water Retention and Nutrient Availability to Ligustrum lucidum," Horticultural Science, Vol. 21, 1986, pp. 1159-1161.

[18] J. M. Woodhouse and M. S. Johnson, "The Effect of a Gel Forming Polymer on Seed Germination and Establishment," Journal of Arid Environments, Vol. 20, 1991, pp. 375-380.

[19] M. Silberbush, E. Adar and Y. De-Malach, "Use of an Hydrophilic Polymer to Improve Water Storage and Availability to Crops Grown in Sand Dunes I. Corn Irrigated by Trickling," Agricultural Water Management, Vol. 23, No. 4, 1993, pp. 303-313. doi:10.1016/0378-3774(93)90042-9

[20] A. M. Al-Omran and A. R. Al-Harbi, "Improvement of Sandy Soils with Soil Conditioners," In: A. Wallace and R. E. Terry, Eds., Handbook of Soil Conditioners: Substances That Enhance the Physical Properties of Soil, Marcel Dekker, Inc., New York, 1997, pp. 363-384.

[21] A. I. Al-Humaid and A. E. Moftah, "Effects of Hydrophilic Polymer on the Survival of Buttonwood Seedlings Grown under Drought Stress," Journal of Plant Nutrition, Vol. 30, No. 1, 2007, pp. 53-66. doi: $10.1080 / 01904160601054973$

[22] A. K. Bhardwaj, I. Shainberg, D. Goldstein, D. N. Warrington, G. C. Levy, "Water Retention and Hydraulic Conductivity of Cross-Linked Polyacrylamides in Sandy Soils," Soil Science Society of America, Vol. 71, No. 2, 2007, pp. 406-412. doi:10.2136/sssaj2006.0138

[23] J. M. Anderson and J. S. I. Ingram, "Tropical Soil Biology and Fertility: A Hand-Book of Methods," CAB International, Wallingford, 1993.

[24] D. W. Nelson and L. E. Sommers, "Total Carbon, Organic C and Organic Matter," In: A. L. Page, et al., Eds., Methods of Soil Analysis, Part 2, Agronomy, 2nd Edition, ASA, Madison, 1982, pp. 539-579.

[25] J. M. Bremner, "Total N," In: C. A. Black, et al., Eds., Methods of Soil Analysis, Part 2 Agronomy, ASA, Madison, 1965, pp. 1149-1178.

[26] R. H. Bray and L. K. Kurtz, "Determination of Total Organic and Available Forms of Phosphorus in Soils," Soil Science, Vol. 59, No. 1, 1945, pp. 39-45. doi:10.1097/00010694-194501000-00006

[27] J. R. Okalebo, K. W. Gathua and P. L. Woomer, "Laboratory Methods of Soil and Plant Analysis Manual," TSBF-CIAT and SACRED Africa, Nairobi, 2000.

[28] G. Vogel Willis, “A Guide for Revegetating Coal Mine 
Soils in the Eastern United States," Department of Agriculture, Forest Service, Northeastern Forest Experiment Station, 1981, $190 \mathrm{p}$.

[29] K. F. Wenger, "Forestry Hand Book," John Wiley \& Sons Inc., Hoboken, 1984.

[30] D. C. Bowman, R. Y. Evans and J. L. Paul, "Fertilizer salts Reduce Hydration of Polyacrylamide Gels and affect Physical Properties of Gel-Amended Container Media," Journal of American Society of Horticultural Science, Vol. 115, No. 3, 1990, pp. 382-386.

[31] D. L. Bouranis, A. G. Theodoropoulus and J. B. Drossopoulus, "Designing Synthetic Polymers as Soil Conditioners," Communications in Soil Science and Plant Analysis, Vol. 26, No. 9-10, 1995, pp. 1455-1480. doi:10.1080/00103629509369384

[32] Z.-B. Luo, K. Li, X. Jiang and A. Polle, "Ectomycorrhizal fungus (Paxillus involutus) and Hydrogels Affect Performance of Populus euphratica Exposed to Drought Stress," Annals of Forest Science, Vol. 66, No. 1, 2009, p. 106. doi:10.1051/forest:2008073

[33] Y. Shi, J. Li., J. Shao, S. Deng, R. Wang, N. Li, J. Sun, H. Zhang, H. Zhu, Y. Zhang, X. Zheng, D. Zhou, A. Hüttermann and S. Chen, "Effects of Stockosorb and Luquasorb Polymers on Salt and Drought Tolerance of Populus popularis," Scientia Horticulturae, Vol. 124, 2010, pp. 268-273.

[34] J. Abedi-Koupai and J. Asadkazemi, "Effects of a Hydrophilic Polymer on the Field Performance of an Orna- mental Plant (Cupressus arizonica) under Reduced Irrigation Regimes," Iranian Polymer Journal, Vol. 15, No. 9, 2006, pp. 715-725. doi:10.1016/j.scienta.2009.12.031

[35] J. L. Moya, F. R. Tadeo, A. Gómez-Cadenas, E. PrimoMillo and M. Talón, "Transmissible salt Tolerance Traits Identified through Reciprocal Grafts between Sensitive Carrizo and Tolerant Cleopatra Citrus Genotypes," Journal of Plant Physiology, Vol. 159, No. 9, 2002, pp. 991998. doi:10.1078/0176-1617-00728

[36] M. Ahmad and H. Verplancke, "Germination and Biomass Production as Affected by Salinity in Hydrogel Treated Sandy Soil," Pakistan Journal of Forestry, Vol. 44, No. 2, 1994, 53-61.

[37] P. J. Kramer and J. S. Boyer, "Water Relations of Plants and Soils," Academic Press, San Diego, 1995.

[38] B. Duan, Y. Lu, C. Yin, O. Junttila and C. Li, "Physiological Responses to Drought and Shade in Two Contrasting Picea asperata Populations," Physiologia Plantarum, Vol. 124, No. 4, 2005, pp. 476-484. doi:10.1111/j.1399-3054.2005.00535.x

[39] R. Van-den-Boogaard, D. Alewijnse, E. J. Veneklaas and H. Lambers, "Growth and Water-Use Efficiency of 10 Triticum aestivum Cultivars at Different Water Availability in Relation to Allocation of Biomass," Plant, Cell and Environment, Vol. 20, No. 2, 1997, pp. 200-210. doi:10.1046/j.1365-3040.1997.d01-60.x 